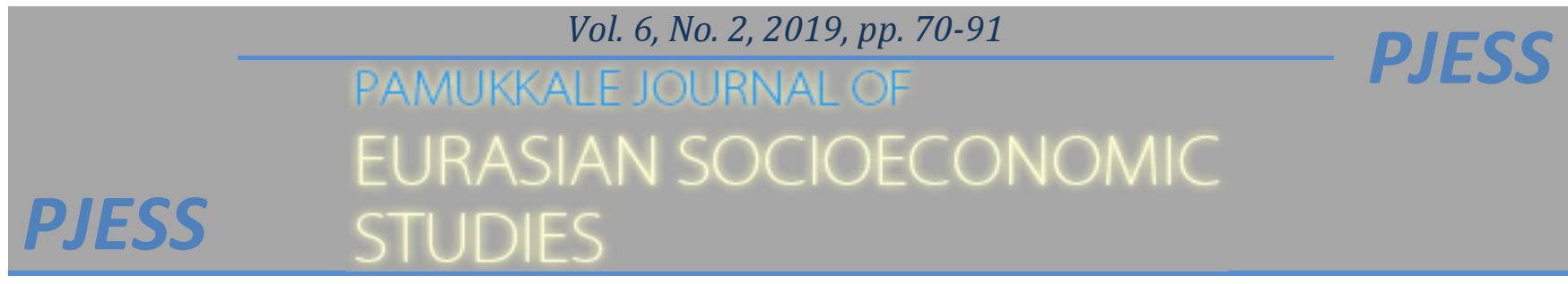

\title{
Piramidin Tabanında Saklı Hazine Ters İnovasyon Hakkında Bir Tarama
}

\author{
The hidden treasure at the bottom of the pyramid: A review about reverse \\ innovation
}

\begin{abstract}
Ahmet BARDAKCI ${ }^{1 \text { a }}$
Şeyda GÜRKAYNAK GÜRBÜZER ${ }^{2}$

Bahar AKYILDIZ ${ }^{3}$

${ }^{1}$ Pamukkale Üniversitesi, İktisadi ve İdari Bilimler Fakültesi, Denizli. abardakci@pau.edu.tr ${ }^{2}$ Pamukkale Üniversitesi, Sosyal Bilimler Enstitüsü, Doktora Öğrencisi, Denizli. gurkaynaks@gmail.com ${ }^{1}$ Pamukkale Üniversitesi, Sosyal Bilimler Enstitüsü, Doktora Öğrencisi, Denizli. akyldzbhr@gmail.com

a Yazışlan yazar/Corresponding author
\end{abstract}

\section{Özet}

Çokuluslu şirketler yıllarca fakir ülkeleri farklı hatalı varsayımlara bağlı olarak ihmal ettiler. Fakirler ülkelerin yeterince cazip olmadığı görüşünden kurtulamadılar. 2000'li yıllarda özellikle General Elektrik (GE) Să̆lık bölümünün Hindistan'da ve Çin'de başlattığı projelerin çıktıları Prof. Vijay Govindarajan'ın dikkatini çekti. Bu örnekler Uluslararası Mamul Hayat Ĕgrisi teorisi ile çelişiyor hatta aksini işaret ediyordu. Bu makale özellikle öğrencilerin kavramla tanışmalarına yardımcı olmak için ters inovasyon kuramın literatürdeki örneklerle ele almaktadır.

Anahtar kelimeler: Yükselen pazarlar, Ters inovasyon, Piramidin Tabanı

JEL kodlarn: M16, M31, M39.

\begin{abstract}
Multinational companies have disregarded poor nations believing some misassumptions. They couln't disengage the idea that poor countries were not attractive as required. The successful outcomes of two projects initiated by General Electric Health division in India and China took attention of Prof. Vijay Govindarajan. These cases seem to be conflicting with well known International Product Life Cycle theory even referring the reverse. This article aims to introduce the concept of reverse innovation with real cases to our students.
\end{abstract}

Keywords: Emerging Markets, Reverse innovation, Bottom of the Pyramid

JEL codes: M16, M31, M39 


\section{GİRIŞ}

Uluslararası iktisat ve işletme literatürü Vernon'dan (1966) bu yana inovasyon olarak ifade edilen yeniliklerin, gelişmiş pazarlarda ortaya çııı yavaş yavaş gelişmemiş ülkelere doğru yayılacağını varsaymıştır. Fakat günümüzde International Product Life Cycle (IPLC) teorisi her zaman destek bulamamakta, aksine gelişmekte olan pazarlardan gelen inovasyonlar gelişmiş pazarlarda popülerliğini gün geçtikçe arttırmaktadır (Petrick ve Juntiwasarakij, 2011). $\mathrm{Bu}$ gerçeğin göz ardı edilmesi, bir yandan işletme ve iktisat alanındaki araştırmacılara kendilerini sürekli batı dünyasını izlemek zorunda hissetmelerine yol açarken diğer yandan mühendislik ve tıp alanlarındaki araştırmacıların da inovasyon için sürekli teknolojinin yoğun olduğu alanlara odaklanmalarına neden olmaktadır. Bu tür odaklanmalar doğal olarak gelir piramidin tabanındaki geniş pazarların şu ana kadar gözden kaçırılmasına yol açmıştır. Piramidin tabanında milyarlarca potansiyel tüketicinin inovasyonlara aç olduğu, ilk olarak Prahalad \& Hart (2002) o zamanlar günlük 1,90 \$US altında yaşayan dört milyardan fazla insanı referans alarak ifade edilmiştir (Hadengue vd. 2017).

Piramidin tabanını hedefleyen inovasyonların zaman içerisinde gelişmiş ülke pazarlarında başarı kazanması IPLC teorisinin öğretilerine aykırı bir sonuçtu. Fakirin zengine öykünmesi doğaldı ama zenginin fakire öykünmesi uluslararası işletmecilerin ezberlerini bozmuştu. İlk kez Immelt vd. (2009) ve Govindarajan \& Trimble (2013) tarafından yayınlanan bu ezber bozan teoriye ters inovasyon adı verilmişti. Saatin yönü IPLC kabul edildiğinde, bu yeni olgu saatin ters istikametine işaret ediyordu. Govindarajan'nın gözlemlerine göre batıda bir dönem çok popüler olan netbookların atası fakir ülkelerdeki çocuklardır. Quanta Computer tarafından üretilip 175 \$US satılan bilgisayarlardan etkilenen ASUS, gelişmekte olan ülkeler için kendi netbookunu tasarladı ve ASUS EEE markasıly 200 \$US satışa sundu. Üründe kullanılan teknolojinin geliştirilip, kalitesinin yükselmesine bağlı olarak ASUS EEE satışlarının zengin ülkelerde hızla yükselmek yanında yeni bir kategorinin doğmasına yol açtı (Govindarajan \& Trimble, 2013).

Bu makale Govindarajan'ın ters inovasyon kavramı ile Prahalad ve Hart'ın piramidin tabanı kavramlarını bir araya getirmeyi hedefleyen bir literatür taraması olarak hazırlanmıştır. Amacı, ülkemizde az sayıda çalışmaya konu olan (örn. Büyük ve Gümüştekin, 2017; Sarıkaya ve Kök, 2018) piramidin tabanı için inovasyon konusunda bir farkındalık oluşturmasına katkı sağlamaktır. Bu sayede piramidin tabanındaki hazine hakkındaki önyargıları ortadan kaldırabilmek ve inovasyon noktasında sadece gelişmiş ülke tüketicilerinin olası ihtiyaçlarına odaklanma miyopluğundan kurtulmak mümkün olabilecektir. Çalışma alan yazında ters inovasyon olarak değerlendirilen örneklerle zenginleştirilmiştir.

\section{PİRAMIDİN TABANI KAVRAMI}

Geleneksel işletme okulu dünyadaki ana pazarların Ohmae (1986) tarafından işaret edilen ve Triad olarak adlandırılan Kuzey Amerika, Batı Avrupa ve Japonya'dan oluştuğunu kabul ederek, yoksul pazarları çoğunlukla ihmal etmektedir. Aykırı bir görüş Prahalad \& Hart'tan (2002) gelmiştir. Yazarlar, günlük 1 \$US altında bir gelire sahip yaklaşık 4 milyar insan (2000 yılı için) gerçeğinden hareketle, gelişmekte olan ve az gelişmiş ülkelerdeki yoksulların Çokuluslu Şirketler (ÇŞ) için stratejik öneme sahip olduklarını iddia etmişlerdir. Temel ihtiyaçlarını bile karşılamaktan uzak olan, dünyanın yaklaşık yarısını oluşturan gelir piramidinin tabanında yer alan yoksul toplumlar (Dünya Bankası, 2018a) gerçekten ÇŞlerin 
kar hedefine ulaşması için yeteri kadar büyük müdür? Govindarajan \& Trimble (2012) inovasyonun geleneksel anlayışa bağlı olarak sadece zenginler arasında talep edileceği şeklindeki hatalı varsayıma işaret ederek, dünya pazarlarına Detroit yerine Delhi'den bakmayı öneriyorlar. Detroit'ten bakınca nispeten pahalı ürünler için yeterli olmayacak gibi duran talebin, Delhi'den bakınca zengin bir altın madenine dönüşebileceğinin altını çiziyorlar.

\begin{tabular}{|c|c|c|}
\hline $\begin{array}{c}2015 \text { Kişi Başına GSYH, Atlas } \\
\text { Metot (Cari US\$) }\end{array}$ & Tabaka & Nüfus (Milyon Kişi) \\
\hline $20000 \$$ den fazla & & 1018246660 \\
\hline $1500 \$-20000 \$$ & $2 \& 3$ & 5543100834 \\
\hline 1500 \$ den az & 4 & 849662350 \\
\hline
\end{tabular}

Kaynak: World Bank (Toplam 110479041 kişiye ait GNI bilinmemektedir.)

Dünya Bankası raporlarına göre dünyada aşırı yoksulluk 1990'lardan bu yana Sahra Altı Afrika ülkeleri dişındaki epeyce gerilemiştir. 2015 yılında dünya nüfusunun \%26,2'si, (1,933 milyar insan) günlük 3,20 \$US altında ve dünya nüfusunun yaklaşı $\% 46$ 's günlük 5,50 \$US altında bir gelire sahiptir (Dünya Bankası, 2018b). Sahra Altı Afrika'da 1990 yılında 278 milyon olarak hesaplanan aşırı yoksul sayısı 2015'de 413 milyon kişiye yükselmiştir. Dünyanın en yoksul 28 ülkesinin, 27'si de Sahra Altı Afrika'da bulunmaktadır (World Bank, 2018: 2). Sahra Altı Afrika ile karşılaştırıldığında Hindistan'da aşırı yoksulluk oranı çok düşüktür. Ancak 1,5 milyara yaklaşan devasa nüfusu nedeniyle Hindistan'da çok sayıda aşırı yoksul bulunmaktadır günlük 1,90 \$US altında geliri olan 170 milyon kişi olduğu tahmin edilmektedir (World Bank, 2018: 4, 29). Aşırı yoksulluğun en yoğun olduğu ilk beş ülke arasında Hindistan'ın yanı sıra Bangladeş, Demokratik Kongo Cumhuriyeti, Etiyopya ve Nijerya bulunmaktadır

Yoksul ülkelerin çoğunda nüfusun \%40'1 günlük 1,90 \$US eşiğinin altında gelire sahiptir. Çoğunluğu kırsal alanlarda yaşayan bu insanlar, tarıma ve dolaysıyla iklime aşırı bağımlıdır. Uganda' da kuraklık ve haşereler yüzünden gelirde düşüşler yaşanmış 2012' de \%35,9 olan yoksulluk oranı 2016'da \%41,6'ya yükselmiştir (World Bank, 2018: 5).

Dünya genelinde toplumlar giderek zenginleşmekte, aşırı yoksulluk giderek azalmaktadır. 20 yıl önce küresel nüfusun $\% 60$ 'ı düşük gelirli ülkelerde yaşarken, bu oran 2015'de \%9 olarak hesaplanmıştır. Bu azalma, dünyadaki yoksullarının çoğunun günümüzde orta gelirli ülkelerde yaşadığına işaret etmektedir. Bu kaymayı ve insanların gereksinimlerindeki değişimleri yansıtması için Dünya Bankası 2011 fiyatlarını temel alarak, kişi başına günlük 3.20 \$US ve 5.50 \$US olmak üzere iki yeni yoksulluk eşiği belirlemiştir. Bu eşikler sırasıyla düşük orta ve yüksek orta gelirli ülkelerin yoksulluk sınırını işaret etmektedir. Aynı yolla International Poverty Line (IPL) günlük 1,90 \$US, en yoksul ülkelerden bir kısmının tipik yoksulluk sınırından hareketle belirlenmiştir. Daha yüksek değerli eşikler ülkelerin gelir 
düzeylerine bağlı olarak temel gereksinimlerin neler olduğuna dair toplumsal değerlendirmeleri yansıtmaktadır (World Bank, 2018: 7). Temel ihtiyaçlar ülkeden ülkeye, ülkenin geliri ve tüketim düzeyine göre farklılaşmaktadır. Yoksul ülkelerde işgücüne katılım, sadece yiyecek ve giyecek gerektirirken, zengin ülkelerde internet bağlantısı, ulaşım ve cep telefonu da gerekecektir. Dolaysıyla aynı işi gerçekleştirmenin maliyeti ortalama gelir ve tüketim düzeyine göre ülkeden ülkeye farklılaşacaktır. Şekil 1'de görüleceği üzere, dünya nüfusunu nerdeyse yarısı (\% 46) tipik bir üst orta gelir grubundaki ülkenin yoksulluk sinırı olan günlük 5.50 \$US den daha az gelire sahiptir (World Bank, 2018: 7). IPL eşiğinin altında olanların sayısı 1990' da 1,9 milyar kişi iken 2015 yılında 736 milyon kişi olarak hesaplanmıştır. Bu dönemde dünya nüfusundaki 2 milyar kişilik artışa rağmen, IPL sınırının altındakilerin sayısında 1 milyar kişilik bir azalma olmuştur (World Bank, 2018: 19).

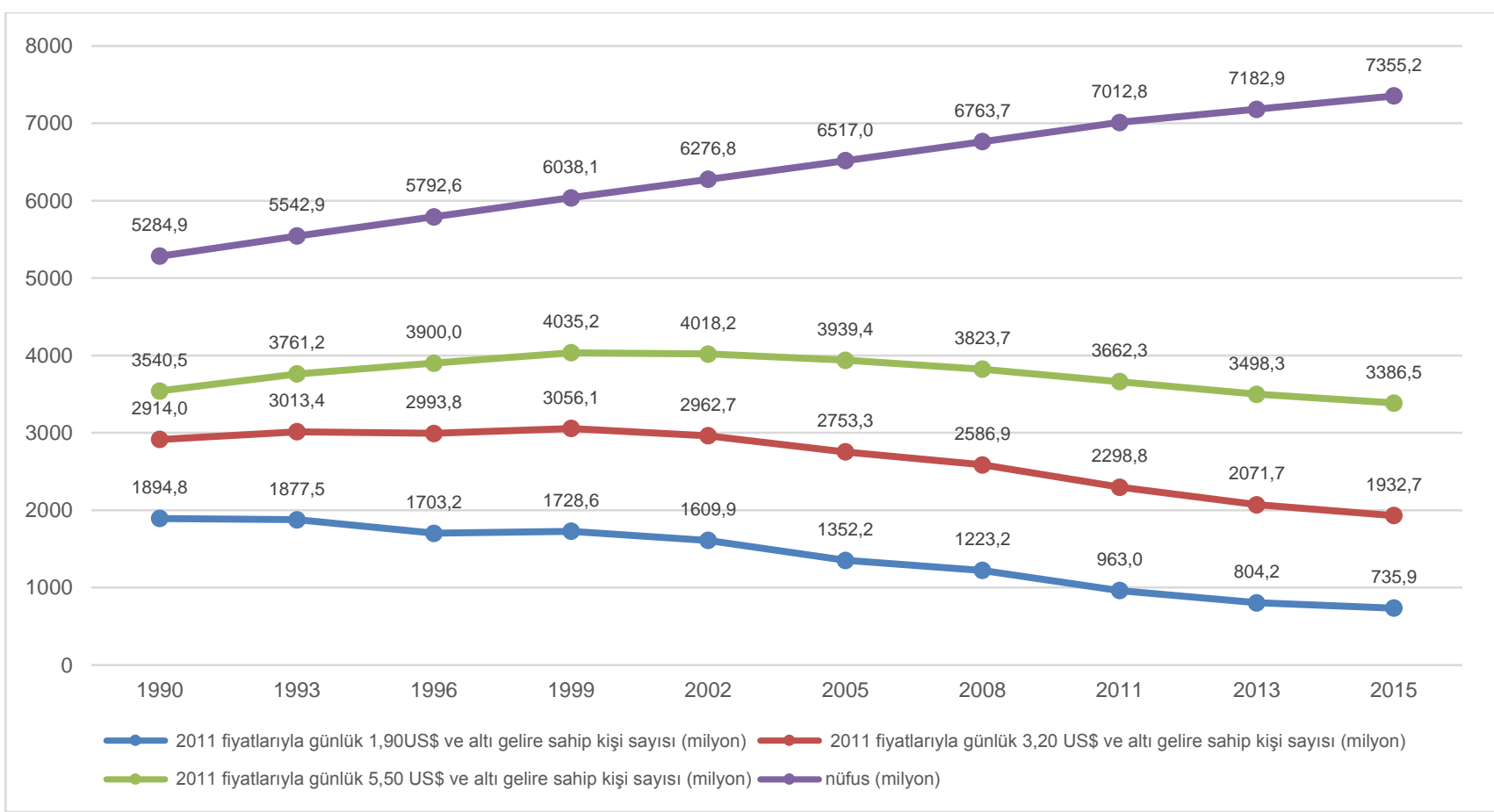

Şekil 1. 1990-2015 Dünya Gelir Dağılımı

\section{TERS İNOVASYON}

İnovasyon yazınında değişik türden inovasyonları tanımlamak için farklı kavramlar kullanılmıştır. Bu tanımlar çoğunlukla birbirlerinden tamamen ayrıştırılmamış, aynı örnekler farklı inovasyonlar için örnek göstererek kavramsal karmaşa arttırılmıştır. Yıkıcı (Distruptive), iktisatlı (Frugual) ve ters (Reverse) inovasyon bu bağlamda aralarındaki çok sayıda ortak özelliğe bağlı olarak birbirinden net şekilde ayrıştırabilen bir çalışma maalesef ortaya konulamamıştır (Shan \& Khan, 2014; Hadengue vd., 2017).

IPLC (Vernon, 1966) kuramına göre inovasyonlar gelişmiş ülkelerde kitlesel pazar tarafından benimsendikten sonra sırasıyla gelişmekte olan ve az gelişmiş ülkelere doğru hareket eder. Hem Roger'ın (Wikipedia, 2019d) inovasyonun yayılımı (diffusion of innovation) hem de IPLC teorileri temelde bu kabule dayanmaktadır. Uluslararası pazarlama ve uluslararası işletmecilik literatürüne göre de inovasyonun ülkeler arasındaki akışı bu şekilde gerçekleşir. Ancak Govindarajan günümüzde bu akışın tersine de olabileceğini, yoksul ülkeden zengin 
ülkeye akabileceği görüşünü savunmaktadır. İnovasyonun benimsenme açısından hareketi geleneksel anlayışın tersine düşünüldüğünden kavram için "ters" (reverse) sıfatı tercih edilmiş, kavram ters inovasyon olarak nitelendirilmiştir (Govindarajan \& Ramamurti 2011; Hadengue vd., 2017). Govindarajan'ın tanımı çok sayıda yazar tarafından özümsenmiş olsa da (örn. Zmuda, 2011; Radojević, 2013; Shan \& Khan, 2014) bazı yazarlar gelişmekte olan veya az gelişmiş ülkelerdeki her türden inovasyonu ters inovasyon sınıfına dâhil etmeleri kavramın çok iyi anlaşılmadığının (örn. Corsi \& Zedtwitz, 2016; Büyük \& Gümüştekin, 2017) bir göstergesidir. Hatta bu yanılgıya The Economist (2010: 3) de düşmüştür. Dergi konu hakkında yayınladığı özel ekinde Nike'ın Müslüman bayan sporcular için vücudun tamamını kapatan formasını, Mercedes'in arka koltuklara eklediği iklimlendirme kontrol ünitesini ve Tata Chemicals tarafından o zamanlar geliştirilme aşamasında olan su arıtma cihazını ters inovasyon olarak aktarmıştır.

Ters inovasyon kavramını ortaya atanlara göre terslikte esas olan bir inovasyonun ilk olarak geliştirildiği ülke değil, inovasyonun benimsendiği ülkedir. Çin veya Hindistan gibi yükselen pazarlarda kitlesel olarak benimsenen bir inovasyon diğer yükselen pazarlara ve nihayetinde gelişmiş ülkelerin pazarlarına aktarılmış ise bu bir ters inovasyondur (Govindarajan \& Ramamurti, 2011; Hadengue vd., 2017).

Ters inovasyon geleneksel olarak uygulanan zengin ülkeler için geliştirilen karmaşık ürünlerin basitleştirilmesi (glokalization) değildir. Govindarajan'ın sık sık ifade ettiği gibi ters inovasyon yoksul pazarın ihtiyacına uygun yeni baştan bir tasarımdır. Hadengue vd. (2017) ters inovasyonun yoksulara dönük yenilikler içermediğini, yoksul tüketicilerin kendi bağlamlarından kaynaklı yenilikleri içerdiğini belirtmektedir. İlerleyen bölümlerde görüleceği üzere General Electric elektrokardiyogram $(E K G)$ ve Ultrason cihazları gelişmiş ülkelerde var olan EKG makinelerinin özelliklerinin azaltılması ile ortaya çıkmamış, Hindistan'ın veya Çin'in özgün ortamlarına uygun şekilde yeniden icat edilmiştir. Ortaya çıkan ürünün yeni, üründe kullanılan ana fikrin eski olmasından hareketle Hadengue vd. (2017) ters inovasyonun hem yeni hem de eski fikirleri ihtiva eden bir yapısı olduğunu belirtmiştir.

Govindarajan \& Ramamurti'nin (2011) ters inovasyon kavramı, mucidinin kökeni ile de ilgilenmez. İnovasyonu geliştiren firma gelişmekte olan ülke kökenli olsa örneğin Vestel, Triad pazarları için örneğin; çamaşırları ütüsünü bozmadan yıkayan bir çamaşır makinesi icat etse, bu inovasyon bir ters inovasyon değildir. Çamaşır makinesinin yıkama kapasitesinin Hindistan'daki geniş aileler için 15kg çıkarılmasında da terslik yoktur. Peru için geliştirilmiş olan GiraDora markalı az su kullanan ve pedalla çalışan çamaşır makinesinin sonradan Triad'ta kampçılar ve karavancılar arasında yoğun ilgi görürse buna ters inovasyon denilecektir. İnovasyonu icat eden firmanın veya icat edildiği yerin ters inovasyon kavramında yeri yoktur, benimsenmenin yönü önemlidir. The Economist dergisi başta olmak üzere, bazılarının düştüğü bir diğer hata da icatçı firmanın merkezinden veya icat edildiği ülkeden hareket etmektir. Bu yüzden bazı kaynaklarda bulunan Huawei, Lenovo, Hairer (The Economist, 2010: 3) gibi Çin ve Hindistan temelli şirketlerin büyümesi üzerinden verilen örneklerin de ters inovasyonla bir ilgisi bulunmamaktadır.

Prahalad \& Hart (2002) piramidinin tabanında başarının sadece ürüne ilişkin inovasyonla değil pazarlamanın diğer bileşenlerine ilişkin inovasyonlarla da olabileceğine dikkat çekmektedir. Zengin pazarlardaki ortalama tüketicilerin, yoksul pazardakilere nispetle 
yüksek harcanabilir gelirlerinin yanı sıra yüksek miktardaki satın alımlarını uygun şekilde depolama imkânları da bulunmaktadır. Bu nedenle alışverişlerini haftalık hatta aylık olarak yapabilirler. Yoksul pazarlardaki ortalama tüketicilerin ise fazla parası neredeyse hiç olmaz ve bunlar günlük yaşarlar. Yoksulların evleri de oldukça küçüktür. Dahası Sahra altı Afrika ve Hindistan kırsalındaki evlerin çoğunda bir buzdolabı yoktur. Bu nedenle yoksul insanlar, her gün, azar azar alışveriş yaparlar. Buna bağlı olarak Hindistan'da hali hazırda kişisel bakım ürünlerinin ve şampuan, çay ve ilaç gibi tüketim ürünlerinin \%30'u tek kullanımlık paketlerde satılmaktadır.

Ters inovasyonu konu edinen makalelerde sık karşılaşılan bir inovasyon türü de "İktisatlı" inovasyondur. İktisatlı inovasyon, ters inovasyon ile çok sayıda ortak özelliği paylaşmaktadır. Aralarındaki en önemli fark; iktisatlı inovasyon yükselen pazarlar için ortaya konulmuştur fakat bunların gelişmiş ülkelere yayılması gerekli değildir (Hadengue vd., 2017). Bu anlamda Hindistan'daki Husk Power ve Chotukool ile Afrika'daki Envirofit iktisatlı inovasyon için gösterilebilecek en güzel örneklerdendir. Bunlar Hindistan' da ve Afrika' da insanların hayatını önemli şekilde değiştirmişlerdir ancak şu an için sadece Hindistan'da veya Afrika'da bulunuyorlar. İktisatlı innovasyonun bu tanımı World Intellectual Property Organization (WIPO) (2013) ve Radojević (2013)'de görülebilmektedir. Ancak The Economist (2010: 3) dergisi Govindarajan'ın ters inovasyon kavramını araştırmacıların "Iktisatlı" veya "Kısıt Temelli" (Constraint Based) inovasyon olarak adlandırdığını ifade ederek, kendisi de iktisatlı inovasyonun gelişmekte olan ülkelerden doğup, gelişmiş ülkelerde de satılan inovasyon olarak tanımlamıştır (Economist, 2010: 14). Bu doğrultuda kavrama GE'nin Çin için tasarladığı sonrasında gelişmiş ülkelerde de talep gören ultrason cihazı ile Dr. Shetty'nin Cayman Adaları'nda, inşa ettiği 2.000 yataklı hastane örneklerini vermiştir. Bu sayede İktisatlı inovasyon ve ters inovasyon kavramların karıştırılmasına katkı sağlamıştır.

İktisatlı inovasyon konusundaki tek kitabi yazan (Frugal Innovation: How to do more with less) Navi Radjou (2014, 2015 ve 2017) TedTalks' da İktisatlı inovasyonu herkes [yoksullar] için ulaşılabilir ucuz çözümler olarak ele almaktadır. Radjou'nun örnek çözümleri de glokalizasyon kapsamında basitleştirilmiş ürünler değildir. Hossain (2017) iktisatlı inovasyonlar için "ucuz, sağlam, kullanımı ve tamiri kolay, yerli materyallerle mevcut teknoloji düzeyini yakalayan inovasyon" demektedir. Shan \& Khan (2014) iktisatlı inovasyonun maliyeti düşürebilmek için sadece bir ürünün yeniden tasarlanması olarak değil tüm sürecin yeniden gözden geçirilmesi ile ilgili olduğunu belirmişlerdir.

Radjou'nun iktisatlı inovasyon için sıklıkla başvurduğu örnek, Hindistan'da Mansukhbhai Prajapati tarafından geliştirilip üretilen MittiCool markalı elektriksiz, pişmiş topraktan yapılma muhafaza (buz)dolabıdır. Bosch firması tarafından Türkiye'de üretilip Afrika pazarlarına satılan elektriksiz soğutucu Fresh Box piramidin tabanındaki büyük problemi çözmek üzere geliştirilmiş yeni bir iktisatlı inovasyondur. Literatürde hiç ele alınmayan bu çözüm aslında MittiCool markasıyla satılan pişmiş topraktan soğutucunun geliştirilip endüstriyel hale getirilmiş halinden başka bir şey değildir. Fresh Box örneği Radjou'nun (2019) iktisatlı inovasyon tanımı ile birebir örtüşmektedir. İlerleyen zamanlarda gelişmiş ülkelere de farklı amaçlar için (örneğin kampçılık, balıkçılık veya çiftçilerin tarlada kullanımı için) satılmaya başlanırsa, iktisatlı inovasyon, ters inovasyona dönüşmüş olacaktır. İktisatlı inovasyon kavramına verilen örneklerden biri de Siemens tarafından Çin pazarı için geliştirilen Somatom Bilgisayarlı Tomografi (CT scanner) cihazıdır. Vakaya ait ticari 
kaynaklardaki bilgilere bakılırsa bu cihazın geliştirilme sürecinin de sonraki süreçlerin de izleyen bölümlerde detaylı olarak ele alınacak VScan cihazının geliştirilme sürecinden çok fark1 yoktur.

Shan \& Khan (2014) iktisatlı inovasyonda, ürünlerin sadece gelişmekte olan ülke insanları için değil, tüm dünya için geliştirilmesi gereğini öne sürerler. Bu kapsamda ki ender örneklerden birisi her çocuğa 100 \$US dizüstü bilgisayar hedefiyle çııılan yolda icat edilen meyvelerinden olan netbook bilgisayarlardır.

Y1kıc1 (distruptive) innovasyon kavramının mucidi Christian Christiensen'dir. "Yıkıcı" sıfatı daha az kaynağa sahip nispeten küçük firmaların, pazarın hâkim firmalarına başarılı şekilde meydan okumasına işaret etmektedir. Bu nedenle şu iki meydan okumadan doğmamış inovasyonlar yıkıcı değildir. (1) Pazarın hâkim firmaları ürün ve hizmetlerini en kârlı ve en talepkâr müşterilerin isteklerine göre sürekli geliştirmekle meşguldür ve daha az talepkâr müşterilerine daha az vakit ayırırlar. Bir inovasyon hâkim firmaların yok saydığ 1 düşük gelirli, alt kısımlardan doğmuşsa "Yıkıcıdır". (2) İnovasyon daha önce kimsenin olmadığı yeni pazarlarda kendisine zemin bulmuşsa yani tüketici olmayanları tüketici haline getirmişse "Yıkıcıdır". Bu iki maddenin herhangi birinden doğmayan inovasyon yıkıcı değildir. Ticari taksilere alternatif olarak gösterilen Uber örneğin bu iki zeminden de doğmamıştır dolayısıyla "yıkıc1" değildir (Christensen, Raynor ve McDonald. 2015; Christensen, Ojomo ve Dillon, 2019). Kavramın ters inovasyon ile karıştırılmasının sebebi; her ikisinde de işaret edilen "pazarın altı" kavramı olabilir. Fakat Govindarajan bu kavram ile uluslararası yoksulluk sınırı olan 1,90 \$US altında geliri olanlara işaret ederken, Christiensen sadece Hindistan'ın veya Afrika'nın yoksullarına değil her ülkenin kendi yoksuluna işaret etmektedir (Shan \& Khan, 2014). Pazarın yoksullarını hedefleyen inovatif ürünlerin performansları arttıkça bu ürünler gelişmiş ülkelerin varlıklı müşterilerine de cazip gelmeye başlayarak yukarıya doğru hareket etmiş olabilirler. Bu doğrultuda bazı yıkıcı inovasyonların aynı zamanda ters inovasyona dönüşeceğini düşünmek yanlış değildir (Hadengue vd., 2017). Yıkıcı inovasyon kavramında inovasyonun nerede geliştirildiğinin veya ilk olarak hangi gelişmişlik düzeyindeki ülkede benimsendiğinin önemi yoktur. Christiensen kendisi konuyla ilgili yazdıklarında ve sunumlarında sürekli Hintli Godrej \& Boyce firması ile birlikte geliştirdikleri "Chotukool" markalı soğutucuyu öne çıkarmaktadır. Yukarıda ele alınan FreshBox örneğine tekrar dönüldüğünde buzdolabı üreten devler, Hindistan'da olduğu gibi Sahra Altı Afrika'da da fakirleri ihmal etmiştir. FreshBox'a kadar Bosch veya aynı aileden Siemens'in yoksullara dönük bir ürünü yoktur, ayrıca pazarda yoksulların gıdalarını muhafaza etmesi için ürün sunan başka marka da yoktur. Bu halde Fresh Box Afrika' da böyle bir ürünü ilk tanıtan firma olduğundan bu örnek yıkıcı bir inovasyon olarak da düşünülebilir.

İktisatlı ve yıkıcı inovasyonlar, ters inovasyonun ön aşamasıdır (Zeschky vd., 2014). Gerçekten gelişmekte olan bir ülkede ortaya çıkarılan inovasyonların bir kısmı gelişmekte olan ekonomilerde kalmak zorundaymış gibi gözükmektedir, örneğin köylere santrallerden elektrik hattı çekmeye gerek duymadan köyün sadece aydınlatma için kullanılacak elektriğini pirinç çeltiğinden üreten HuskPower bunlardan birisidir.

Görebildiğimiz kadarıyla literatürde İktisatlı inovasyon ile Yıkıcı inovasyon arasındaki farkı ele alan bir çalışma yoktur. Ancak kavramlar için hem seçilen örnekler ve hem de açıklamalar 
iktisatlı inovasyon ile Yıkıcı inovasyonun arasında fark olmadığına, her ikisinin de aslında aynı kavram olduğuna işaret ediyor.

\section{PIRAMIDIN TABANI İÇIN İNOVASYON NIÇIN İHMAL EDILMEMELİ?}

Govindarajan \& Trimble, (2013) Hindistan'daki yoksullar için yapılacak bir inovasyonun izleyen yıllarda gelişmiş pazarlara da cazip geleceğini düşünüyor. Bu bağlamda gelişmiş ülkelerin ÇŞlerı bugün piramidin tabanındaki pazarlara dönük inovasyonlara yönelmezlerse, bu alanı gelişmekte olan ülkelerin firmalarına bırakmış olacaklardır. Govindarajan \& Trimble (2013) çimento endüstrisinde Meksikalı Cemex'in inovasyonlarıyla İsviçreli Holcium'u ve Fransalı Lafarge'ı sollamasına; telekomünikasyon alanında Çinli Huawei'in, Siemens, Eiicsson, Alcatel ve Cisco gibi devlere meydan okumasına, Hindistanlı Mahindra \& Mahindra'nın düşük güçteki traktör pazarında dünya devi Deere \& Company'i ABD'de zorlamasına dikkatleri çekiyor. Çin merkezli tıbbi cihaz üreticisi Mindray, rüzgâr türbini üreticileri Hindistan merkezli Suzlon ve Çin merkezli Goldwind ile yine Çin merkezli beyaz eşya ve tüketici elektroniği üreticisi Haier (Immelt vd., 2009) dünyanın en büyük dördüncü bilgisayar üreticisi Lenovo, dünyanın en büyük çelik üreticisi Endonezyalı ArcelorMittal ve dünyanın en büyük üç bira şirketinden birisi olan South African Breweries (The Economist, 2010: 7) kendilerine ayrılan alanı iyi kullanarak devler ligine yükselen şirketler arasındadır.

Yoksullar için de inovasyona ağırlık verilmez ise alanın yeni inovatif firmalarca doldurulacağı iddialarını destekler nitelikte 2018 yılında Forbes' in açıkladığı en inovatif 100 şirket listesinde Hindistanlı beş, Çinli yedi firma bulunuyor. Aynı listede Tayland, Endonezya, Brezilya, Rusya ve Şili'den de birer şirket bulunuyor (Forbes, 2019). Benzer doğrultuda Corsi ve Zedtwitz (2016) batılı ÇŞlerin uzun zamandır karmaşık teknolojilerinin gelişmekte olan ülkelerdeki rakipler tarafından anlaşılamayacağını ve tersine mühendislik olmayacağını varsayarak, bu teknolojilerin arkasına saklandığını ancak doğuluların hızla yol aldığına; Japonya ve Güney Kore örneklerinden hareketle, Çin ve Hindistan tehdidine işaret ediyor.

Radojević (2013) gelişmiş ekonomilerin ÇŞlerinin ters inovasyona odaklanmalarının olası faydalarını şöyle sıralıyor: (1) dünya nüfusunun önemli bir kısmı gelişmekte olan pazarlarda yaşamaktadır ve bu pazarlar yüksek büyüme oranına sahiptir. 2015'de dünyadaki 735,9 milyon aşırı yoksulun 175,7 milyonu Hindistan'da yaşamaktaydı (World Bank, 2018: 43). Bu kadar aşırı yoksula rağmen Hindistan 2017 ve 2018' de \%7' nin üzerinde büyümüştür. (2) Her ülkede aslında gelir bir piramit şeklinde dağılmaktadır sonuçta her ülkede koşulları farklı da olsa yoksullar bulunmaktadır. ÇŞler Hindistan'daki çoğunluk için ortaya çıkardıkları inovasyonlarını gelişmiş ülkelerdeki yoksullara da sunabilirler. (3) Batılı ÇŞler az gelişmiş dünyanın insanının ihtiyacına cevap vermekte yetersiz kalırsa, bu ülkelerin yerel firmaları bu boşluğu dolduracak ve ilerleyen dönemlerde batılılara rakip olacaklardır.

Sonuç olarak yoksul ülkelerdeki insanların problemini çözecek yerel firmalar varken gelişmiş ülke ÇŞlerinin sadece gelişmiş ülke pazarlarına yoğunlaşmasının sürdürülebilir olmadığ1 düşünülmektedir. Gelişmekte olan pazarlar için yapılan inovasyonların, gelişmiş pazarda başarılı olması ve gelecekte yeni ve zorlu rakiplerle karşılaşma ihtimali; yüzlerce batılı ÇŞyi Hindistan ve Çin'e Ar \& Ge merkezleri kurmaya sevk etmiştir. 2010 yılında Fortune 500 listesindeki şirketlerin Çin'de 98, Hindistan' da 63 adet Ar-Ge merkezi olduğu raporlanmıştır (The Economist, 2010: 2). 


\section{ZENGINIIN YOKSULA ÖYKÜNÜŞÜ}

İbni Haldun'un taklit teorisini de çağrıştıran yoksulun, zengine öykünmesi (Bardakcı \& Akınc1, 2014) son derece anlamlıdır. Ancak Govindarajan' in ters inovasyon kavramı; zenginin, yoksula öykündüğü kurgusuna dayanmaktadır. Govindarajan \& Trimble (2013) buna gerekçe olarak dört olası neden ortaya atmaktadır.

1. Yoksul ülkelerde, zenginler için üretilen ürünlere ilgi gösterecek zenginler bulunduğu gibi, zengin ülkelerde, düşük fiyatlı ürünleri cazip bulabilecek çok sayıda yoksul bulunur. Rakamlar kabaca; İngiltere' de 13,44 milyon (Department for Work and Pensions, 2016) ABD'de 43,1 milyon, Fransa'da 8,8 milyon (Secours Catholique, 2019). Türkiye'de 11 milyon (Dünya Bankası, 2019b) yoksul insan bulunmaktadır. Ancak unutmamak gerekir ki gelişmiş dünyanın fakiri ile piramidin tabanındaki fakirlerin gelirleri arasında devasa farklar vardır. Gelişmemiş ülkenin fakiri günlük 2011 rakamlarıyla 1.90\$ kazanırken İngiltere' nin fakiri haftalık 400£ elde etmektedir (Wikipedia, 2019a). Ülkemizde ise günlük 1,90\$ US altında gelire sahip kişi oranı 2000'den 2018'e yaklaşık 12 kat azalarak 165000 kişiye düşmüştür (Dünya Bankası, 2019b).

Düşük fiyatlı konut, tıbbi hizmet veya bankacılık - tele banka, mikro finans- alanındaki yenilikler gelişmiş ülkelerdeki yoksullara cazip gelebilir (Govindarajan \& Ramamurti, 2011). Sağlık alanında batılı hastalar nispeten düşük fiyata iyi bakım sağlayan yükselen ekonomilere akmaya başlamıştır. Bu alandaki lider ülkelerden birisi Hindistan' dır (Petrick \& Juntiwasarakij, 2011). Hindistan hükümet kaynaklarına göre 2017 yılında 495.056 yabancı tedavi olmak üzere Hindistan'ı ziyaret etmiştir. Hindistan'da sağlık sektörün 2020'de 9 milyar \$US büyüklüğe ulaşması bekleniyor (Suri, 2009). 2017 yılında 1,4 milyondan fazla ABD'li tedavi amaçlı ülke dışına çıkmıştır.

2. Gelişmekte olan pazarlar için aşırı düşük maliyetli olacak şekilde yeniden tasarlanan ürünler, gelişmiş ülke pazarlarına sunulduklarında talebin fiyat esnekliğine bağlı olarak çok daha yüksek bir taleple karşılaşır. Ölçek etkisi ve deneyim eğrisi nedeniyle düşen maliyetlere ve fiyatlara bağlı olarak artan talebin çok sayıda örneği vardır, -televizyonlar, fotokopi makineleri, kişisel bilgisayarlar vb. (Hall \& Howell, 1985 aktaran Govindarajan \& Ramamurti, 2011).

3. Ürünler gelişmekte olan pazarlar için yeniden tasarlandığında boyutları küçülüp taşınabilir hale gelebilir, kullanımı kolaylaşabilir. Bu yeni özellikler gelişmiş ülkelerde ürünün farklı kullanım alanlarını dolayısıyla yeni bir büyüme ortaya çıkarabilir. Örneğin General Electric firmasının, EKG cihazları büyük ve pahalı iken batıdaki hastanelerin çoğunda sadece bir cihaz bulunuyordu. Ters inovasyonla Hindistan'dan gelen ucuz ve taşınabilir EKG cihazları sonrasında neredeyse her poliklinikte ve cankurtaran aracında bulundurulmaya başlanmıştır (Govindarajan \& Ramamurti, 2011).

4. Gelişmekte olan ülkeler için geliştirilen ucuz ve nispeten basit ürünler gelişen teknolojiye bağlı olarak gelişmiş ülkedeki müşteriyi tatmin edene kadar yeniden geliştirilebilir. Teknolojik gelişmeler sayesinde, GE'nin Çin'de geliştirdiği portatif ultrasonlar, bir zamanlar karmaşık ve pahalı makineler gerektiren radyoloji ve ultrasonografi fonksiyonları yerine getirmiştir (Immelt vd., 2009 aktaran Govindarajan \& Ramamurti, 2011).

$\mathrm{Bu}$ arada çoğu batılı ÇŞ geçmişten gelen alışkanlıklarından vazgeçmeyerek dünya ekonomisindeki gelişmelerin az gelişmiş ülkeler üzerindeki yansımalarını iyi okuyamadılar. 
Geçmişte olduğu gibi fakirin hala fakir kaldı̆̆ını, küreselleşmenin pozitif etkilerinin sadece kendi ülkelerindeki tüketiciler için ortaya çıkacağını düşünmek bu firmalarda bir dizi hatalı varsayıma yol açmıştır. Literatürde yoksul ülkelerle ilgili hatalı olduğu söylenen varsayımlar şunlardır:

1. Yoksulun parası yoktur. İlk bakışta anlamlı gözüken bu varsayım aslında doğru değildir. Bireylerin ortalama gelirleri bir makro gösterge olarak çok düşük olsa da, bir bütün olarak toplumun alım gücü yüksektir (Prahalad \& Hammond 2002; McCloud, 2010). Zengin ülkelerde her biri çok para harcayan az sayıda tüketici bulunurken, gelişmekte olan ülkelerde her biri az para harcayan çok sayıda tüketici bulunur. Bu nedenle piramidin tabanındaki toplam harcama tahmin edildiğinden büyüktür (Prahalad \& Hart, 2002; Prahalad \& Hammond, 2002; Govindarajan \& Trimble, 2013). Örneğin bir an için sadece Çin ve Hindistan'ı düşünürsek buralarda az harcama yapan yaklaşık 3 milyar kişi vardır. Bunların tamamının günlük 2 \$ harcadığını varsaysak toplam rakam günlük 100 \$ harcayan 60 milyon tüketiciye, 50 \$ harcayan 120 milyon tüketiciye denktir. Ayrıca makro göstergelerin ortalama geliri gösterdiği ve gelirin tekdüze dağılmadığı unutulmamalıdır.

2. Yoksullar sadece temel ihtiyaçlarını satın alır, gereksiz ürünlerden uzak durur. Yoksullar da lüks ürünler satın alırlar. Kevin McCloud (2010a) tarafından hazırlanan "Slumming It" belgeseli dünyanın en büyük gecekondu bölgelerinden birisi olan Mumbai'deki Dharavi'nin milyar dolarlık ekonomiye ev sahipliği yaptığını ortaya koymaktadır. Buradaki halkın evlerinde televizyon, düdüklü tencere, buzdolabı ve cep telefonu gibi modern dünyaya ait eşyalar kolayca seçilebilmektedir.

3. Gelişmekte olan ülkelerde satılan ürünlerin ucuz olması gerektiğinden kar marjları da yüksek olamaz. Bu ülkelerde tefecilerin faiz oranları gelişmiş dünyanın finansal kurumlarının faizlerinden çok daha yüksektir, gelişmiş dağıtım altyapıları yoktur bu nedenlerle aslında bu tür ülkelerde örneğin içme suyuna ödenen bedel çoğu gelişmiş ülkedekinden daha yüksektir (Prahalad \& Hammond, 2002).

4. Piramidin tabanındakiler gelişmiş teknolojileri kullanamazlar. Bangladeş kırsalındaki yoksul kadınlar cep telefonu kullanırken zorlanmiyor. Kenya'nın gecekondu bölgelerinde gençler web tasarımı konusunda başarılı şekilde eğitilebiliyor. El Salvador'lu yoksul çiftçiler ürünlerinin internet üzerinden satmak için telefonları ve bilgisayarları rahatlıkla kullanabiliyor. Hindistan sahillerindeki kadınlar PC kullanımını öğrenip, internet üzerinden Arap körfezindeki balık yoğunlaşmalarını izliyor ve balık avındaki eşlerini buralara yönlendiriyorlar. Bunlar gibi onlarca, yüzlerce örnek yoksul toplumların yaşam kalitelerini artıracak fırsatlara dönüştürebilmek üzere yeni teknolojileri benimsemeye herkes kadar hazır olduklarını gösteriyor (Govindarajan \&Trimble, 2013).

5. Yoksullar gelişmiş ülke ÇŞleri tarafından sömürülmektedir. Yoksul toplumlara hizmet veren kayıt dışı ekonominin oyuncuları etkin ve verimli değildir ve sömürüyü aracılar yapar. Tefeci faizlerinin \%100'leri bulduğu bu ülkelerde mikro kredi kuruluşları ve Citigroup gibi finans kurumları çok daha düşük faizlerle kredi sağlamaktadır? (Prahalad \& Hart, 2002; Prahalad \& Hammond, 2002; Govindarajan \& Trimble, 2013)

6. Gelişmekte olan ekonomiler, gelişmiş ekonomilerin geçtiği yolları izleyecektir. Gelişmekte olan ülkeler, gelişmiş ülkelerin izlediği yolu izlemek zorunda değildir, siyah beyaz tüplü televizyonları hiç görmeden renkli LCD kullanmaya başlayan birçok toplum vardır. Sahra Altı Afrika ülkeleri kablolu telefon altyapılarına yatırım yapmamıştır ama 
cep telefonları yaygın şekilde benimsenmiştir. Geçmişteki nispeten pahalı, şimdikilere göre hantal altyapı yatırımları yapılmak ve bunların sınırları içinde kalınmak zorunda değildir (Çavusgil vd., 2016: 63).

Günümüzde Hindistan 19.yy ABD'si ile aynı konumdadır. 19yy New York'unda atlar ve faytonlar vardı. Televizyon, radyo bilgisayar veya cep telefonu yoktu. Bugünkü Mumbai motosikletlerle doludur. Cep telefonları oldukça yaygındır, radyo ve televizyon neredeyse her eve girmiştir. Günümüz toplumları insanlığın en eski sorunlarını en yeni teknolojiyle çözme avantajına sahiptir. Bu bağlamda gelişmişlerin izlediği geçmişte kalan yolun bugün izlenmesi zorunlu olmadığı gibi aksine izlenmemesi bile gerekebilir. Ancak Hindistan'ın kırsalında elektrikle tanışmamış veya elektriğe güvenemeyen çok sayıda birey bulunmaktadır. Bunları zengin dünya için tasarlanmış üründe pahalı birkaç özelliği çıkarılarak uyarlamak, yani glokalizasyon kullanarak tatmin etmek mümkün değildir. Glokalizasyon yaklaşımı sınırlar arasındaki küçük bazı farklılıkları çözebiliyor olsa da zengin ve yoksul ülkeler arasındaki uçurumu kapatmak için yeterli değildir. Buzdolabını ele alalım batıda yaklaşık 100 yıldır kullanılan ürün elektriğin evlerde kullanımı ile yaygınlaşmıştır. Teknolojinin elverdiği ölçüde elektriksiz, oldukça düşük fiyatlı, ulaşılabilir dağıtım ağıyla uyumlu bir buzdolabı icat etmeden, geçmişin hantal, çok enerji tüketen, batının elektrik dağıtım ağları ile uyumlu buzdolaplarıyla Hindistan'da başarının kazanılması mümkün değildir (Govindarajan \& Trimble, 2013).

\section{BAŞARININ KOŞULU}

Piramidin tabanındaki potansiyeli fark eden firmalar bu potansiyelden istifade edebilmek için kolları sıvamışlar ve çabalarının meyvelerini toplanmaya başlamışlardır. Akademide adları değişmiş olsa da içeriği aynı gibi duran "İktisatlı", "Yıkıcı", “Ters" "Kapsayıcı" (inclusive), "tabandan gelen" (grassroots) ve "Jugaada" inovasyonlar vardır. Bu inovasyon türlerinin hemen hepsinin ortak paydası piramidin tabanındaki genellikle yoksul köylüler için oldukça ucuz ama yeterli faydayı sağlayan bir ürünü ortaya çıkarmasıdır. İçlerinden sadece ters inovasyon, bir adım ileriye giderek inovasyon'un IPLC'ye ters yayılımına işaret etmektedir.

Yoksullar için oluşturulacak inovasyonun, yoksulun yaşam koşullarından doğması gerektiği Govindarajan \& Trimble (2013) tarafından sıkça dillendirilmiştir. Yazarların bu konuda "ters inovasyon icat etmekle değil unutmakla başlar", "Ters inovasyon sil baştan inovasyon dediğimiz şeydir" ifadeleri bulunuyor. Gelişmiş pazarlar ile yükselen pazarlar arasında derin farklar bulunuyor (Govindarajan \& Ramamurti, 2011). Triad olarak adlandırdığımız zengin pazarlar dünya pazarlarının önemli bir oranına karşılık geldiği dönemlerin çözümlerinden olan glokalizasyon günümüzün yükselen pazarları için yeterince etkili çözümler sunamıyor. Eskiden dünyanın neresinden olursa olsun yoksullar ÇŞlerce potansiyel bir pazar olarak değerlendirilmiyordu. Afrika kırsalında ürün satmayı kimse aklından geçirmiyordu çünkü ne altyapı ne de orta sınıf tüketici vardı. Ayrıca geçmişte ürünleri ucuza mal edebilmek için gerekli bileşenlerin dışarıdan tedarik edilmesi mümkün değildi. Bugün yükselen pazarlarda özellikle Çin' de ve Hindistan' da giderek büyüyen bir orta sınıf yanında farklı bileşenleri daha ucuza tedarik etme imkânları var. Bu doğrultuda Prahald \& Hart (2002) sonrasında konuyu ele alanlar ÇŞlerin glokalizasyona dayalı küresel stratejilerini günümüzün gerçekleriyle

\footnotetext{
a İktisatlı inovasyon için kullanılan bir başka kavram. https://www.thinkwithgoogle.com/marketingresources/jugaad-innovation/
} 
uyumlu hale getirmesi gerektiğinin altını çiziyor. Yükselen pazarların uyarlanmış ürünleri değil, kendi koşullarına göre yeniden icat edilmiş ürünleri istediğinin altını çiziyorlar (Prahalad, 2005; Govindarajan \& Ramamurti, 2011; Govindarajan \& Trimble, 2013).

Bir kısmı izleyen kısımlarda ele alınacak olan MAC400, MAC600, M-Pesa, Grameen Bank, Envirofit, Chotukool Mahindra \& Mahindra, Giradora, Q Drum, Hippo Roller vb. örneklerin tamamının yükselen ekonomilerin "yok"larından hareketle icat edildiğini gösteriyor. Ters inovasyon konusunda literatürde bahsedilen örneklerden bazıları buraya özet olarak alınarak, konunun hem yükselen hem de gelişmiş ekonomilerde aldı̆̆ı yollarla okuyucularımıza fikir vermesi hedeflenmiştir.

\section{GE EKG Cihazlarl, Hindistan}

Hekimler Hindistan' da en yaygın ölüm nedeninin kalp krizi olduğu ve erken teşhisin kalp krizini önlemede son derece önemli olduğunu belirtiyorlar (Radojević, 2013). Bangalore merkezli GE Health bölümü de 2001'den itibaren yüksek kaliteli EKG cihazlarını Hindistan'da geliştirip üretmekteydi. Ancak AR\&GE merkezi çalışanları Banglore'daki doktorları ziyaret ettiklerinde kendi ürettikleri cihazları göremiyorlardı. GE'nin EKG cihazları yaklaşık 3.00010.000 \$US aralığında satılmaktaydı. Yüksek kalitedeki bu cihazlar taşınamayacak kadar ağır, düzenli bir elektrik akımına ihtiyaç duyan ve bir PC üzerinden yazıcıya bağlanması gereken cihazlard1 (Govindarajan \& Trimble, 2013).

Hindistan geneline yayılmış yedi yüz bin civarındaki pratisyen hekimin EKG cihazlarına erişimi mümkün olursa önemli bir toplumsal sorunun üstesinden gelinebileceğini fark eden GE, aynı zamanda son derece büyük bir pazar potansiyelini de fark etmişti. Bu doğrultuda başlatılan MAC400 projesinin amacı EKG cihazının hayat kurtaran teşhis gücünü Hindistan'ın kırsal bölgelerindeki çoğu yoksul 700 milyonluk nüfusa yaymaktı, zira teşhisten yoksun hastalarının çok büyük çoğunluğu kırsal bölgelerde yaşıyordu (Govindarajan \& Trimble, 2013). 2010 yılında Hindistan'da kişi başına düşen gayri safi milli hâsıla 1.477 dolardı ve yoksulluk oranı \% 29,8 idi. 2010 yılı nüfusu 1,24 milyar varsayılırsa, Hindistan'da piramidin altında neredeyse 370 milyon kişi yaşamaktaydı.

Hint yoksullarının milyonlarcası Mumbai gibi şehirlerin gecekondu bölgelerinde yaşıyor olsa da, piramidin tabanı belli bölgelere yoğunlaşmış değil dağınık haldedir. Hindistan nüfusunun \%72'si Hindistan boyunca dağılmış 600.000'den fazla köyde yaşamaktadır. Hindistan'da piramidin tabanı sudan, yiyeceğe, yağa gaza, temel eğitimden temel sağlık hizmetlerine kadar büyük ölçüde kıtlıkla karşı karşıyadır. Böyle bir pazarda "daha fazlasını daha aza satın alma ihtiyacl, hayat memat meselesidir" (INSEAD, 2011: 77; akt. Radojević, 2013).

Anladığımız kadarıyla Govindrajan'ı inovasyon akışının tersine de olabileceğine ikna eden en etkileyici vaka da GE India tarafından Hindistan'ın özellikleri göz önünde bulundurarak geliştirdiği MAC400 EKG cihazının batıda kazandığı başarının hikâyesidir. 
Tablo 1. Hindistan Pazarı İçin EKG cihazı Hedefleri ve Sonuçları

\begin{tabular}{|c|c|c|}
\hline & Hedef & Sonuç \\
\hline $\begin{array}{l}\text { Düşük teşhis } \\
\text { maliyeti }\end{array}$ & $\begin{array}{l}\text { Geleneksel cihazlarla gerçekleştirilen bir EKG } \\
\text { testinin 5-20 \$US arasında değişen maliyeti } \\
\text { Hindistan için oldukça yüksekti. Her ne kadar } \\
\text { erken teşhis edilemeyen bir vaka sonradan çok } \\
\text { daha pahalı, belki de ölümcül sonuçlara yol } \\
\text { açacak olsa da, bu fiyat çoğu yoksulu göğüs ağrısı } \\
\text { hissettiğinde hastaneye başvurmaktan } \\
\text { caydırabilecek kadar yüksekti. Ortaya çıacak } \\
\text { ürünün teşhis maliyetleri yerel pazarda kabul } \\
\text { sınırları içerisinde olmalıydı. }\end{array}$ & $\begin{array}{l}\text { MAC400 kullanılmaya başladığında Bangalore } \\
\text { gibi şehirlerde hastalar her EKG için } 90 \text { Rupi } \\
\text { (2\$US), kırsaldaki hastalar ise } 45 \text { Rupi (1US\$ } \\
\text { dolar) ödüyordu. Bu fiyatlar geleneksel } \\
\text { modellerin 5-20\$US fiyatının çok altındaydı. } \\
\text { Ancak sonradan bu fiyatların bile potansiyel } \\
\text { müşteriler tarafından oldukça yüksek } \\
\text { bulunduğu fark edildi. }\end{array}$ \\
\hline $\begin{array}{l}\text { Düşük yatırım } \\
\text { maliyeti }\end{array}$ & $\begin{array}{l}\text { MAC400 cihazı öncesinde GE Health tarafından } \\
\text { Hindistan'da satılan en ucuz cihaz 3,000 \$US } \\
\text { civarındaydı. Bu fiyat ortalama bir klinik için } \\
\text { oldukça pahalıydı. Bu maliyetlere sadece } \\
\text { şehirlerdeki büyük hastanelerere gelen hastalar } \\
\text { katlanabilirdi. MAC } 400 \text { 'ün fiyatı kliniklerin ve } \\
\text { hatta pratisyenlerin satın alabilecekleri aralığa } \\
\text { indirilmeliydi. }\end{array}$ & $\begin{array}{l}\text { EKG ile test hastanın vücudunun verdiği elektrik } \\
\text { sinyallerinin, dijital sinyal işlemcisi (DSI) ile } \\
\text { okunabilir hale getirilir. GE'nin kullandığı tescilli } \\
\text { DSİ'leri göreceli olarak az sayıda üretildiği için } \\
\text { maliyetleri yüksekti. Fakat Texas lnstruments ve } \\
\text { Analog Devices gibi üreticilerde kolayca } \\
\text { bulunabilen DSI'ler, ölçek ekonomisi nedeniyle } \\
\text { çok daha ucuzdu. } \\
\text { Düşük maliyetli yazıcı tasarlamak için yürütülen } \\
\text { bir dizi girişimin ardından ekip Banglore'daki } \\
\text { belediye otobüslerinde kullanılan bilet } \\
\text { yazıcılarından yararlanmaya karar verdi. } \\
\text { Otobüslerde MAC400'ün EKG çıtıları için } \\
\text { kullanılabilecek boyutta, ağırlıkta ve } \\
\text { dayanıklılıkta bir yazıcı kullanılmıştı. Her yıl bu } \\
\text { yazıcılardan yüzbinlerce satılıyordu. GE Health } \\
\text { yılda yalnızca on bin birimlik üretim yapmak } \\
\text { yerine bunlardan satın alarak önemli bir tasarruf } \\
\text { sağladı. }\end{array}$ \\
\hline Taşınabilirlik & $\begin{array}{l}\text { Hindistan kırsalında nüfus dağınık haldedir. } \\
\text { Klinikler ve pratisyenler nispeten az sayıdadır ve } \\
\text { her yerde bulunmazlar. Hastaların düzenli } \\
\text { olarak izlenmeleri sağlıkları açısından büyük } \\
\text { önem taşıyor olsa da, çoğu hasta en yakın kliniğe } \\
\text { düzenli kontrol için sık sık uğrayamayacak kadar } \\
\text { uzaktadır. Belirtiler endişe verici hale geldiğinde } \\
\text { bunun için gerekli yolculuk göze alınabilir. Bu } \\
\text { nedenle projede taşınabilirliğe önem verilmiş, } \\
\text { doktorlar klinikte hasta beklemek yerine, cihazı } \\
\text { hastalara götürebilmeli diye düşünülmüştür. }\end{array}$ & $\begin{array}{l}\text { Cihazın kolayca taşınabilmesi için biçimi } \\
\text { küçültmek konusunda da gelişme kaydedildi. } \\
\text { Hedeflenen toplam ağırlı } 1,1-1,2 \quad \mathrm{~kg} \text {. } \\
\text { arasındaydı. Yazıcı boyutlarının küçültmesi } \\
\text { cihazın ağırlığını ve kapladığı alanı azaltmıştı. }\end{array}$ \\
\hline Güç kaynağı & $\begin{array}{l}\text { Hindistan'da genelinde kırsalda elektrik ya } \\
\text { yoktur ya da güvenilebilir nitelikte değildir. } \\
\text { Elektrikle çalışacak bir cihazın kırsalda işe } \\
\text { yaramayacak ya da son derece sınırlı kalacaktı. } \\
\text { MAC400 şebeke elektriği yanı sıra bir batarya ile } \\
\text { de çalışabilir olmalıydı. }\end{array}$ & $\begin{array}{l}\text { Gösterge panelinin devreden çıkarılması; teknik } \\
\text { karmaşa yanında hem toplam ağırlığı hem de } \\
\text { elektrik tüketimini azaltmıştı. Ayrıca şarjl } \\
\text { bataryanın ömrünü de uzatıyordu. Tek bir şarjla } \\
\text { en az } 100 \text { EKG testi hedefine ulaşıldı }\end{array}$ \\
\hline Kullanım kolaylığı & $\begin{array}{l}\text { MAC400 yalın olmalı ve sınırlı eğitim almış } \\
\text { yardımcı sağlı personeli tarafından da } \\
\text { kolaylıkla kullanabilmeliydi. }\end{array}$ & $\begin{array}{l}\text { MAC400'de cihazı çalıştırmak için bir yeşil } \\
\text { düğme, durdurmak için bir kırmızı düğme } \\
\text { bulunuyor. Trafik 1şıkların bilen birisi } \\
\text { MAC400'ü de kullanabilir. }\end{array}$ \\
\hline $\begin{array}{l}\text { Bakım ve onarım } \\
\text { kolaylığı }\end{array}$ & $\begin{array}{l}\text { Hindistan'da tıbbi teknolojinin satıs sonrası } \\
\text { hizmet altyapısı kırsalda gelişmemiştir. } \\
\text { Karmaşık bir cihazın kırsal bir alanda bozulması } \\
\text { halinde cihazı tamir edebilecek bir teknisyene } \\
\text { ulaşmak oldukça çok zordu. MAC400'ün } \\
\text { kolaylıkla onarıbilir olması gerekiyordu. }\end{array}$ & $\begin{array}{l}\text { Cihaz olabildiğince sade, karmaşadan uzak } \\
\text { tasarlanarak üretilmişti. }\end{array}$ \\
\hline
\end{tabular}

Kaynak: Govindarajan \& Trimble, 2013 uyarlanmıştır. 
2010 yılında MAC400 yerini geliştirilmiş sürümü MACIndia'ya bıraktı. MAC400, 800 \$US'dan satılmaktaydı. MAC400'ün tarama başına 45 Rupi fiyatı kırsaldaki Hintliler için katlanılamayacak kadar yüksekti. Göğsünde ağrı hisseden çoğu kişi 45 Rupi ödemek yerine ağrının kendiliğinden geçmesini bekliyordu. Ama kendiliğinden geçmeyen ağrılar birkaç gün sonra kalp krizine yol açıyor ya ölüme ya da daha yüksek maliyetli tıbbi bakıma yol açıyordu. Geliştirilen MACIndia'nın maliyetleri düşürülmüştü bu sayede fiyatı 500 \$US’a inebildi. EKG başına fiyat da 9 Rupi'ye kadar düşmüştü ki bu fiyat düzeyi Hindistan için bir şişe sudan biraz daha pahalıydı (Govindarajan \& Trimble, 2013).

MACIndia'nın görüntüsü MAC400'e benzese de, yazıcıda $80 \mathrm{~mm}$. kâğıt genişliği $58 \mathrm{~mm}$.ye düşürülmüştü. Bu küçülme yazıcının maliyetini düşürmek yanında hem kâğıt hem de elektrik tüketiminde önemli tasarruflar sağlamıştı. En büyük değişiklik ise MACIndia' öncülü MAC400 gibi hem elektrikle hem de pille değil sadece şarjlı pille çalışmasıydı. Daha küçük bir yazıcı kullanımı yanı sıra DSİ' de yapılan iyileştirmeler sayesinde MACIndia bir şarjla 500 EKG taramasını yapabilecek güce ulaştı (Govindarajan \& Trimble, 2013; GE, 2011).

MAC400'de dijital bir bellek kullanılmamıştı. Bu nedenle her bir taramanın çıktısını almadan başka bir tarama yapmak mümkün olmuyordu. Yazıcıda oluşabilecek bir arıza cihazı kullanilamaz hale getiriyordu. MAC400'lerin bir gösterge paneli de bulunmuyordu. Elektrotlardan biri ya da birkaçı hastaya düzgün bağlanmadığında oluşan hata ancak test sonrasında çıktı alma aşamasında fark edilebiliyor ve tüm işlemin tekrarlanması gerekiyordu. MAC400'lerde harf veya rakamlardan oluşan bir tuş da takımı yoktu. Cihazın kullanıcıları hastaların adını veya tanımlayıcı numaralarını cihaza giremiyorlardı. Bunun yerine tarama sonrasında çıtının üzerine bir isim ya da numara yazılıyordu. MACIndia'ya 4,3 inçlik bir ekran eklendi. Operatörler cihaz bağlantılarının doğruluğunu kolaylıkla denetleyebiliyorlardı. Eğer hastanın örneğin göğüs kılı bir elektrotun sinyaline engel oluyorsa, operatör sorunu taramayı sonlandırılmadan fark edip düzeltebiliyordu. Bu özellik bir yandan kâğıt tasarrufu sağlıyor diğer yandan hastanın rahatsızlığının artmasını önlüyordu. MACIndia' ya tuşlu cep telefonlarındakine benzer bir tuş takımı ve yaklaşık 500 EKG taraması depolayabilen bir bellek kartı eklendi. Taramalar PDF dosyası olarak saklanabiliyor, herhangi bir bilgisayarda okuyabiliyordu, gerektiğinde sıradan bir yazıcıdan çıktı alınabiliyor veya eposta olarak paylaşılabiliyordu. Bu devrim niteliğindeki özellik cep telefonlu tıbbın da tohumlarını atıyordu (Govindarajan \& Trimble, 2013; GE, 2011).

MAC400 ve MACIndia modellerinin şekilleri ve büyüklükleri korunarak 2011 yılında 1.200 \$US fiyatla MAC600 pazara sunuldu. Tam bir klavye eklenmiş olan MAC600 büyük şehirlerdeki klinikler ve pratisyen hekimler için daha uygun bir üründü (Govindarajan \& Trimble, 2013; GE, 2011).

MAC400 her ne kadar Hindistan'a özgü koşullara uygun olarak tasarlanmış olsa da, gelişmiş ülkelerde de kendine bir pazar bulmuştur. MAC400'ün satışları Avrupa'da hızla yükselmiştir. Cihaz satın alma gücü daha karmaşık sistemlere yetmeyen, kendi kliniğinde çalışan hekimler için mükemmel bir çözüm olarak görülmektedir. MAC400, MAC600 ve MAC1200 serileri günümüzde neredeyse her ülkede satılmaktadır (Govindarajan \& Trimble, 2013). 


\section{VScan Ultrason Cihazı}

GE Health, Hindistan'da yaşadığı deneyimi Çin'e de aktarmıştır. GE Health 2010 yılında ultrason teknolojisine dayalı olarak cep telefonu büyüklüğünde bir tıbbi görüntüleme cihazı olan Vscan'ı Çin'de üretti. Şarjlı pille çalışan, elde taşınabilen, kullanımı kolay bu aletin tıpta devrim yaptığı ifade edilmektedir (Govindarajan \& Trimble, 2013).

Çin nüfusunun \%90'dan fazlası temel sağlık hizmetleri için köylerde bulunan düşük teknolojiye sahip hastaneler ya da birinci basamak sağlik kliniklerine başvurmaktadır. Kırsaldaki hastalar için alınacak sağlık hizmeti karşılığında ödenecek bedel büyük önem taşımaktadır. Kırsaldaki birinci basamak sağlık hizmetlerinde görüntüleme teknolojisi yoktur. Hastaların şehirlerde bulunan hastanelere başvurmaları gereği, özellikle hastalar için zor olmaktadır, kolaylıkla taşınabilen bir cihazın hastaların ayağına gitmesi önemlidir. Birinci basamakta görev yapan Çinli hekimler zengin ülkelerde sıklıkla görüldüğünün aksine dar bir alanda uzmanlaşmamış, her şeyden anlayabilen pratisyen hekimlerdir. Bu nedenle ultrason cihazlarının kullanımının kolaylaştırılması gerekmiştir (Govindarajan \& Trimble, 2013).

Çin'in koşulları dikkate alınarak tasarlanan ulstrason cihazı VScan'ın dünya geneli satışları 2002'den 2008'e yılda ortalama \%50 ile 60 arası bir büyüme göstererek 4 milyon \$US'dan 278 milyon \$US'a fırlamıştır. Bebek ve anne ölüm oranlarının hala çok yüksek olduğu yoksul ülkelerde eskiden bir hastaneye ulaşabilmek için otobüsle 24 saatten 36 saate kadar süren yolculuklar yapmak zorunda kalan kadınlar şimdi kendi köylerinde ultrason muayenesinden yararlanabilmektedirler (Govindarajan \& Trimble, 2013).

VScan sayesinde gelişmiş dünyada sağlık çalışanları tıbbi görüntülemeyi ambulanslarda veya şehirlerin en ücra köşelerinde gerçekleştirebilir hale gelmişlerdir. Hastanelerde hekimler hastalarının daha pahalı, daha karmaşık testlere girmesine gerek olup olmadığına karar vermek için hızlı teşhisler gerektiğinde (örneğin bir iç kanamanın ve pıhtılaşmanın yerini belirlemek gibi) VScan kullanmaktadır. Ameliyathanelerde anestezi uzmanları iğnelerinin ve sondaların kolayca yerleştirilmesi için VScan kullanabilmektedir (Immelt ve diğ., 2009; Govindarajan \& Ramamurti, 2011; Govindarajan \& Trimble, 2013).

\section{Narayana Hrudayalaya Hastaneleri}

Narayana Hrudayalaya (NH) Hastaneleri, ABD'de 20.000\$ gerçekleşen açık kalp ameliyatını 2.000 \$ altında gerçekleştirerek başta Hindistan olmak üzere sağlık sisteminde devrim yapmıştır. Oldukça düşük fiyatına karşın $\mathrm{NH}$ Hastanelerinin net kar marjı da ABD ortalamasının üzerindedir. Hastanenin kalitesi dünya standartlarındadır. Baypas ameliyatları sonrasındaki ilk otuz gün içinde ölüm oranı $\mathrm{ABD}^{\prime}$ de ortalama \% 1,9 iken NH Hastanesi'nde ortalama \% 1,4 düzeyindedir.

NH Hastanesi, Hintli kalp cerrahı Dr. Devi Shetty tarafından kurulmuştur. Dr Shetty ölçek ekonomileri ve uzmanlaşma bileşiminin kalp cerrahisinde maliyetleri radikal bir şekilde azaltabileceğine inanmaktaydı. Bu doğrultuda kurduğu hastane, kitlesel üretim tekniklerini cerrahi işlemlere uygulayan ender hastanelerden birisidir. Shetty ve 40 kişilik kardiyoloji ekibi Bangalore'daki 1.000 yataklı NH Hastanesinde haftada 600'den fazla kalp ameliyatı gerçekleştirmektedir (The Economist, 2010: 4; Petrick \& Juntiwasarakij, 2011; Govindarajan \& Trimble, 2013). 2010 yılında Dr Shetty, 15.000'den fazla ekibinin diğer üyeleri ise 10.000'den fazla kalp ameliyatı gerçekleştirmişti. Çok sayıda ameliyat, cerrahların belirli operasyonlar 
için son derece önemli tecrübeler edinmelerine imkân sağlamıştır. NH Hastanesi'nde kardiyologlar, diğer hastanelerin aksine, vakitlerini idari işlerle değil cerrahi hizmetlere harcarlar. NH Hastaneleri pahalı tıbbi ekipmanlarını ABD hastanelerinden beş kat daha fazla kullanır. Bu hastanedeki Hintli cerrahlar ABD'li meslektaşlarına oranla iki, üç kat daha fazla ameliyat gerçekleştirir. Bu sayede cerrahlar kalp cerrahisinin spesifik bir alanında uzmanlaşmıştır. Daha fazla deneyim cerrahların öğrenmesini hızlandırmış, becerilerini geliştirmiş ve nihayetinde operasyonların kalitesini yükseltmiştir (Govindarajan ve Trimble, 2013). Günümüzde zincir Hindistan'da 23 hastane, 7 kalp merkezi, 19 aile hekimliği merkezinde yaklaşık 6.000 yatak ile hizmet vermektedir (Narayana Hospitals, 2019).

Hindistan'da elde edilen başarı birçok ABD vatandaşının kalp ameliyatı için Hindistan'a gitmesine yol açtı Bundan cesaret alan NH hastaneleri yenilikçi çalışma sistemini Miami'ye bir saatlik uçuş mesafesindeki Cayman Adalar'ına taşımaya karar verdi. Sağlık sigortası olmayan veya sigorta kapsamı sınırlı olan $\mathrm{ABD}^{\prime}$ liler için $\mathrm{ABD}$ 'deki fiyatlarının yarısına tedavi edecek, iki yüz yataklı hastane 2014 yılında hizmete açılmıştır (Health City Cayman Islands, The Economist, 2010: 14; Govindarajan \& Trimble, 2013).

\section{Aravind Göz Hastanesi}

Kitlesel üretim tekniklerini kullanarak maliyetlerini inanılmaz derecede düşüren bir başka Hintli hastane Aravind Göz Hastanesi' dir. Katarakt ameliyatları zengin dünyadaki göz başına yaklaşık 1.000\$ düzeyinde iken, Aravind Göz Hastanesi bunu 30\$ karşılığında gerçekleştirir. Kurulduğu 1975' den bu yana en az 3 milyon Hintlinin ve 12 milyon başka ülke vatandaşının körlükten kurtulmasina vesile olmuştur (Aravind, 2019a). Göz Hastanesinin stratejisinin ifadesi oldukça basittir: ameliyat sürecini standartlaştırıp, bunu dünyanın en iyi üreticileri kadar verimli ve etkin biçimde gerçekleştirmek. Aravind kendine McDonald restoranlarını örnek alarak, ameliyathanelerin, cerrahların ve hemşirelerin zamanından oluşan çekirdek kaynaklarını zaman çizelgelerine aktarmıştır. Cerrahi süreçlerin her biri aşama aşama ayırılarak, süreçler ve uygulanacak teknikler standartlaştırılmıştır. Bu tek tip süreçler ve uygulamalar tekrarlanabilir olduğundan zaman planlamasının etkinliği artmıştır. Ameliyat sayısındaki yoğunluk da ölçek ekonomilerine neden olmuştur. Aravind oluşturduğu modelinin, etkinliğini 10 kat kadar arttırdığı iddia ediyor. Ameliyatlar son derecede düşük fiyatlarla gerçekleştiriliyor, bunun yanı sıra Aravind ameliyatların yarısını yoksullar için bedava yapıyor ya da daha düşük ücretler tahsil ediyor. Her şeye rağmen \% 35 civarında brüt kar elde ediyor. Aravind hastanesi bağış ya da yardım kabul etmediği halde her üç yılda bir yeni bir hastane açabilecek kadar kazanç sağlayabiliyor. Günümüzde Aravind hastaneler zinciri dünyanın en büyük göz hastanesi haline gelmiş durumdadır. Yıllık yaklaşık 450.000 göz ameliyatı gerçekleştirilir. 11 odalı bir göz hastanesi olarak başladığı yolculuğunda günümüzde bir lisansüstü araştırma enstitüsü, göz cerrahisinde kullanılan aletleri üreten bir tesisi, 13 göz hastanesi, 6 ayakta göz muayene merkezi, 75 göz bakım merkezi olan bir holding haline gelmiş durumdadır (Govindarajan \& Trimble, 2013; Aravind, 2019b). Sadece 2018 yılında 4.183.234 hasta muayene edilmiş ve 478.028 ameliyat, lazer tedavisi ve göz içi enjeksiyon gerçekleştirilmiştir (Aravind, 2019c). Sahibi olduğu göz cerrahisi aletleri üreten tesisi Aurolab markasıyla alanında dünyanın en büyük tesisidir ve aralarında gelişmiş ülkelerinde bulunduğu 87 ülkeye ihracat gerçekleştirmektedir (Aurolab, 2019). 


\section{Grameen Bank, Bangladeş}

1974 yılında Bangladeş Chittagong üniversitesi ekonomi Profesörü Muhammad Yunus, öğrencileriyle birlikte fakir bir köyü ziyaret etti. Burada bambulardan tabure yapan bir kadınla mülakat yaptılar. Kadın her tabureyi yapmak için 15 poysha karşılığı borç aldığını, borcunu \%10 faizle geri ödedikten sonra kendisine 1 poysha kaldığını anlattı. Yunus bu kadının daha düşük faizle kredi alabilirse hayat standardında büyük bir iyileşmenin olacağını fark etti. Bu doğrultudaki çabaları sonunda 1983 yılında güven ve dayanışma temeline dayanan Grameen Bank ("Köylü bankası") kurdu (Grameen, 2019).

Muhammed Yunus yoksulluğu önlemek için borcun, karşılıksız yardımdan daha etkin olacağını görmüştü. Bu yüzden Grameen Bank, kendi icadı olan mikro kredilerle bir iş kurmak isteyen köylü hanımlara fırsat sunmak üzere yola çıkmıştı. Krediler için teminat yerine bir grubun birbirine kefil olmasına dayalı "grup dayanışması", geri ödeme yönteminin haftalık olması ve vadenin olabildiğince uzun tutulması esastı. Küçük gruplar kredi alabilmek için birlikte başvuru yapıyorlar ve birbirlerine kefil oluyorlardı, böylece grup üyeleri arasında dayanışma sağlanıyordu (Wikipedia, 2019b). Muhammed Yunus kredi alanları sonradan tasarruf etmeye özendirdi, bu sayede tasarruflar başka yoksulların finansal özgürlüğe ulaşmasına hizmet edecekti. Bangladeş'te genel olarak hanımlar gelir paylaşımında ve hane halkı kararlarına katılımda arka sıradadır. Grameen bu yüzden yoksulların en yoksulunu hedeflemişti.

2017 yılına gelindiğinde Grameen'in 2600 şubesi ve yaklaşık 9 milyon kredi müşterisi vardı, geri ödeme oranı \%99,6 idi. Kredi kullananların \%97sini kadınlar oluşturuyordu. Banka Bangladeş kırsalının \%97'sini kapsıyordu. Grameen Bank'ın başarısı dünyada 64'den fazla ülkeye ilham kaynağı oldu, hatta World Bank Grameen türü girişimleri destekleme kararı aldı. Grameen bankası Bangladeş yanında zengin ülkelerde de faaliyet göstermeye başladı. 2017 yılı itibarıyla Grameen ABD'nin, 11 ABD şehrinde 19 şubesi ve yaklaşık 100.000 kadın kredi müşterisi vardı (Wikipedia, 2019c).

Grameen büyük bankalar için karlı olamayacak kadar küçük krediler vermiş ve hemen her aşamada büyük ticari bankaların genel geçer kurallarına aykırı davranmıştır. Geleneksel bankalar zenginlere borç verirken, Grameen yoksullara borç vermiştir. Geleneksel bankalar erkek müşterileri tercih ederken, Grameen kadınları seçmiştir. Geleneksel bankalar şehirlerde, Grameen kırsalda genişlemiştir. Geleneksel bankalar teminatı, Grameen güveni esas tutmuştur. Bankalar hukuki sözleşmelere, Grameen grup dayanışmasına güvenmiştir. 1983 'te kurulduğundan bu yana 9 milyar \$US'den fazla kredi vermiş ve \%98 oranında geri ödeme sağlamıştır. 1983, 1991 ve 1992 yılları dışında kar etmiştir. Bangladeş'teki ilk kullanımından bu yana mikro kredi bankacılık modeli yüzden fazla ülkeye yayılmıştır. Günümüzde ABD'de New York'un yoksul mahallelerinde bile faaliyet gösteren bir banka haline gelmiştir (Govindarajan \& Trimble, 2013).

\section{WorldRemit}

1980'lerde Londra'da eğitim gören Ahmet İsmail bir yandan da bulaşıç̧lık yaparak para kazanıyordu. Kazandığı paranı bir kısmını, Doğu Afrika'daki ailesine göndermek için saatler harcıyor fakat buna rağmen oldukça yüksek havale ücretleriyle karşı karşıya kalıyordu. Kendisi gibi milyonlarca Afrikalının, ailelerine destek olmak için fazladan zaman ve para 
harcadığını ilk elden bilen İsmail Ahmed bu sorunu çözmek için 2010 yılında ortakları Catherine Wines ve Richard Igoe ile birlikte WorldRemit'i kurdu. Cep telefonları üzerinden havale hizmeti veren WorldRemit, Afrika için yeni bir dijital hizmet başlattı, bu sayede kıtadan kıtaya para havalesini ve gelen parayı alma işlemini kolaylaştırdı (WorldRemit, 2019).

WorldRemit günümüzde ABD, İngiltere, Avrupa ve Asya ülkelerinden 40'tan fazla Afrika ülkesine para transferi gerçekleştiriyor. WorldRemit'le Afrika'ya para transferi hızlı, güvenli ve düşük maliyetli olarak gerçekleştirilebilmektedir. Transfer işlemlerin \% 90'ından fazlasına birkaç dakika içinde tamamlanmaktadır. Mobil cihazlarla gerçekleştirilen transferlerin \% 70'i en fazla 3 dakika sürüyor. WorldRemit, 2017 yılında Afrika'ya 1,6 milyar dolardan fazla para transferi gerçekleştirdi. Londra merkez yanında Polonya, Filipinler ve ABD'de bölgesel hubları bulunan şirket şu anda 6 kıtada 700 çalışanıyla faaliyet göstermektedir (WorldRemit, 2019).

\section{M-Pesa}

Afrika'nın mobil parası, ters inovasyon için önemli örneklerdendir. Mobil paranın öncüsü MPesa, Vodafone üyesi SafariCom tarafından 2007 yılında Kenya'da ve birkaç ay sonrada Tanzanya'da Vodafone'un yan kuruluşu Vodacom tarafından başlatıldı. Bugün para transferi ve mikro finansman hizmetinin Güney Afrika, DRC, Mozambik, Lesoto ve Misır'in yanı sira Hindistan, Romanya ve Fiji gibi çeşitli pazarlarda 19 milyon müşterisi bulunuyor (Barbosa, 2015).

Orange, MTN ve Airtel Africa gibi diğer operatörler kısa bir süre sonra Afrika'da mobil para hizmetleri rekabetine başladılar ve GSM Association'a göre, bir önceki yıl 37 milyon olan mobil para müşterisi, 2013 yılı sonu itibariyle Sahra altı Afrika'da 61 milyona ulaşmıştı. Pek çok Afrika ülkesinde, bir banka hesabı olmayan ama mobil para hesabı bulunan insan bulunuyor. Bu insanlar alışveriş yapmak, otobüs bileti almak, taksi ücreti ödemek ve müşterilerden para almak için "mobil cüzdanlarını" kullanıyor. Mobil para, daha önce kullanılamayan finansal hizmetlere erişmek için bir banka şubesine veya ATM'ye ulaşamayan insanları ekonomik olarak güçlendirdi ve birçok kırsal Afrikalı'nın hayatını değiştirdi (Barbosa, 2015). Günümüzde M-Pesa Hindistan, Romanya ve Afganistan'da kullanılmaktadır (Vanham, 2017).

\section{SONUÇ}

Geleneksel işletme öğretileri dünyayı, nüfusunun \%15'inden daha azını içeren Triad'dan ibaret görerek yoksul pazarları yok saymaktadır. Temel ihtiyaçlarını bile karşılamaktan uzak olan, dünyanın yaklaşık yarısını oluşturan Gelir Piramidinin tabanında yer alan yoksul toplumlar çokuluslu şirketlerin hedefine girebilir mi? Govindarajan \& Trimble (2012) başta olmak üzere bazı düşünürler dünyaya Detroit yerine Delhi'den bakmayı öneriyorlar. Detroit'ten bakınca nispeten pahalı ürünler için yeterli talep olmayacakmış gibi gözüken durumların Delhi'den bakınca altın madenine dönüşebileceğinin altını çiziyorlar. Son dönemde dünyaya Delhi'den bakmaya başlayanlar, IPLC teorisindeki inovasyon akışını tersine döndüren örneklerden hareketle yoksul ülke pazarları ile ilgili olarak yapılan varsayımların hatalı olabileceğini tartışmaya başladılar. Ters inovasyon kavramı; zenginin, yoksula öyküneceği kurgusuna dayanmaktadır. Bu bağlamda da İbn-i Haldun'un öykünme teorisine de bir aykırılık söz konusudur. 
Fakir ülkelerde de başarılı inovasyonlar ortaya çıkarılabileceğinin ilk işaretlerinden birisi GE firmasının Hindistan'da geliştirdiği MAC400 EKG cihazıydı. Bu efsane ürüne odaklanan düşünürler yükselen ekonomilerdeki farklı inovasyonları farklı pencerelerden ele almaya ve farklı adlarla kavramsallaştırmaya başladılar. Hindistan için geliştirilip batıya ihraç edilen bu efsane ürünün hikâyesi yarım asırdır üzerinde çalışılan IPLC teorisindeki inovasyon akışına taban tabana zıt bir akıştı. Bu akışa Ters İnovasyon adı verilmişti. Bu esnada belirmeye başlayan diğer inovasyon tanımlarıyla farkı net şekilde ortaya konulmayan bu kavramı dünyaca ünlü The Economist dergisi bile karıştırmıştır. Yükselen bir pazardaki ihtiyaç merkezli bu kavramın glokalizasyon kavramı ile de ilişkisi bulunmamaktadır. Ters inovasyon kavramı literatürde hala karıştırılma olasılığı olan İktisatlı, Yıkıcı, vb. inovasyonların daha ileri aşamasıdır. Ayrıca inovasyon ürünle sınırlı da değildir ve olmamalıdır. Pazarlamanın diğer bileşenleri de farklılaştırma amaçlı kullanılabildiğine göre inovasyona konu olabilir.

Küresel firmaları, piramidin tabanını oluşturan fakir pazarlar için inovasyonun yapmaya iten güdünün ne olduğu da ilgili literatürde ele alınmıştır. Öncelikle yoksulun sadece tabandaki ülkelerde değil piramidin tavanındaki ülkelerde de bulunduğunun unutulmaması gerekiyor. Dolayısıyla Hintli yoksul için yapılacak inovasyon izleyen yıllarda gelişmiş pazarın yoksulu için de cazip olabilecektir. Bu bağlamda ÇŞler piramidin tabanındaki pazarlara dönük inovasyona yönelmezlerse, bu alan gelişmekte olan ülkelerin firmalarına bırakılmış olacaktır. Bu iddiayı destekler nitelikte 2018 yılında Forbes'in açıkladığı en inovatif 100 şirket listesinde yükselen ekonomilerden 16 şirket bulunuyor. Ayrıca 2010 yılında Fortune 500 listesindeki şirketlerin Çin' de 98, Hindistan'da 63 adet Ar-Ge merkezi olduğu raporlanmıştı.

Başarı için ÇŞlerin hâlihazıra batı pazarları için geliştirmiş oldukları ürünleri unutup yükselen Pazar merkezli inovasyon yapmalarının başarı için ilk aşama olduğunun altını çizen ters inovasyon literatürüne ait örnekler de bu makalede sıralanmıştır.

Günümüzde başta Çin, Hindistan ve Afrika kıtası olmak üzere sayısı artan bir orta sınıf var, bunların karşılanmamış ihtiyaçlarının bulunduğu ise son derece belirgin bir gerçek. Firmalar bu potansiyeli batıdakilere yakın performans gösteren son derece düşük fiyatlı ürünlerle tatmin edebilirse piramidin altında bir servet yatıyor. Bir ürünün tamamının bir firma tarafından yapıldığ geçmiş dönemlerde bu amaca ulaşmak belki mümkün değildi. Fakat günümüzde şebeke organizasyonlar, outsourcing imkânları sayesinde, MAC400 örneğinde ele alındığı gibi, piramidin tabanındaki ihtiyaçların karlı bir şekilde karşılanmasının mümkün olduğunun öğrencilerimiz yanı sıra uygulamacılara da aktarması açısından bu çalışma önemli görülmektedir.

\section{KAYNAKÇA}

Aravind, (2019a). http://johnbessant.org/2016/04/26/frugal-innovation/\#_ftn3

Aravind, (2019b). https://aravind.org/our-story/)

Aravind, (2019c). https://aravind.org/wp-content/uploads/2019/04/Aravind_Annual-Report2017-18.pdf

Aurolab, (2019). https://www.aurolab.com/aboutus.asp 
Barbosa, H.(2015). "Reverse Innovation: When Developing Countries Have The Answers", 2015-03-15 https://techpolis.com/reverse-innovation-when-developing-countrieshave-the-answers/ e.t., 26.02.2019

Bardakcı, A ve Akıncı, M, (2014). “Türkiye'de Ürün Markalamada Yabancı Dil Kullanımı: Sebepler ve Sonuçlar", Tüketici ve Tüketim Araştırmaları Dergisi, c 6(1), Haziran, ss.126

Büyük, Ö ve Gümüştekin, G. (2017). “Reverse Innovation: Can Innovation Flow From Turkey to Developed Countries?", International Journal of Tourism, Economic and Business Sciences, Vol.1, No.1, ss.9-19

Cavusgil, S.T., Riesenberger, J., \& Knight, G. (2016). International Business: The New Realities, Global Edition, Harlow, UK

Christensen, C.M. Ojomo, E. Ve Dillon, K.(2019), “Sınır Pazarlarını Fethetmek”, Harvard Business Review Türkiye, Ocak

Christensen, C.M., Michael R., and McDonald. R.(2015),"What Is Disruptive Innovation?" Harvard Business Review 93, no. 12, December, pp. 44-53.

Christiensen C.(2019). “Co-creating with Rural Consumers Helps Achieve Inclusive Growth “ https://www.innosight.com/client_impact_story/godrej/

Corsi, S. \& Zedtwitz, M.V.(2016). “Reverse Innovation: A New World Order for Global Innovation?", The European Business Review, November - December ss.73-77

Dalen, J.E. \& Alpert, J.S. (2019). “Medical Tourists: Incoming and Outgoing”, The American Journal of Medicine, Vol 132, No 1, January, Commentary, ss.9-10

Department for Work and Pensions, (2016). "The Households Below Average Income", https://www.gov.uk/government/statistics/households-below-average-income199495- to-201415

Dünya Bankası (2019b). https://data.worldbank.org/country/turkey ve https://databank.worldbank.org/views/reports/reportwidget.aspx?Report Name=Cou ntryProfile\&Id=b450fd57\&tbar $=y \& d d=y \& i n f=n \& z m=n \&$ country $=T U R$

Dünya Bankası, (2018a). https://www.worldbank.org/en/news/press-release/2018/10/17/ nearly-half-the-world-lives-on-less-than-550-a-day

Dünya Bankası, (2018b). Piercing together the powerty puzzle 2018 International Bank for Reconstruction and Development / The World Bank https://openknowledge. worldbank.org/bitstream/handle/10986/30418/9781464813306.pdf

Forbes, (2019). https://www.forbes.com/innovative-companies/list/\#tab:rank_region: Central\%20Asia

GE, (2011). "Market-Relevant Design: Making ECGs Available Across India”, September 30, http://newsroom.gehealthcare.com/ecgs-india-reverse-innovation/

Govindarajan, V., \& Ramamurti, R. (2011), Reverse innovation, emerging markets, and global strategy. Global Strategy Journal, 1: 191-205. doi:10.1002/gsj.23 
Govindarajan, V., \& Trimble, C. (2013). Ters İnovasyon: Evden Uzakta Yarat Heryerde Kazan. Moda Ofset Basım Yayın

Grameen, (2019). http://www.grameen.com/founder-2/\#

Hadengue, M., Marcellis-Warin N ve Warin, T.(2017). "Reverse innovation: a systematic literature review", International JoNurnal of Emerging Markets, Vol. 12 Issue: 2, pp.142-182, doi: 10.1108/IJoEM-12-2015-0272

Hart, S., \& C. K. Prahalad (2002). "The Fortune at the Bottom of the Pyramid", Strategy + Business, first quarter 2002.

Health City Cayman Islands (2019). "Welcome to Health City Cayman Islands", https://www.healthcitycaymanislands.com/

Hossain, M. (2017). "Mapping the Frugal Innovation Phenomenon, Technology in Society", V.51, November, 199-208, https://doi.org/10.1016/j.techsoc.2017.09.006

Hossain, M.(2017). Massing the Frugal Innovation Phenomenon, Technology in Society, V.51, November, 199-208, https://doi.org/10.1016/j.techsoc.2017.09.006

Immelt, J.R., Govindarajan, V., \& Trimble, C.(2009), “How GE Is Disrupting Itself”, Harvard Business Review, October

McCloud K. (2010). "Kevin McCloud on his trip to India", The Telegraph, https://www.telegraph.co.uk/culture/tvandradio/6952436/Kevin-McCloud-on-histrip-to-India.html

McCloud K. (2010a). Slumming it, https://www.youtube.com/watch?v=Im0tHRs9Bng

Narayana Health (2019). https://www.narayanahealth.org/about-us

Ohmae, K.(1986). "Becoming A Triad Power: The New Global Corporation", International Marketing Review, Vol. 3 No. 3, ss. 7-20. https://doi.org/10.1108/eb008307

Prahalad, C.K ve Hart, L.S. (2002). The Fortune at the Bottom of the Pyramid", Strategy+Business n. 26, First Quarter

Prahalad, C.K: ve Hammond, A. (2002), “Serving the World's Poor, Profitabl” september 2002 harvard business review

Radjou N (2014). https://www.ted.com/talks/navi radjou creative problem solving in the face_of_extreme_limits

Radjou, N. (2015). https://www.youtube.com/watch?v=cHRZ6OrSvvI\&t=15s

Radjou, N. (2017). https://frugalinnovationhub.com/en/resources/2017/03/21/the-genius-offrugal-innovation.html

Radjou, N. (2019). https://frugalinnovationhub.com/en/ e.t. 25.10 .2019

Radojević, N. (2013). "Reverse Innovation and the Bottom-of-the-Pyramid Proposition: New Clothes for Old Fallacies?" 3rd Annual Conference Atlas/AFMI, July 8-9, Montreal, Quebec, Canada. 
Sarıkaya, M., \& Kök, S. B. (2018) “Küresel İnovasyonun Yeni Dinamiği: Ters İnovasyon”, editörler içinde Nart, S ve Yıldırım YT (editörler) Current Debates In Management \& Organization V.29 ss.11-26

Secours Catholique, (2019) https://www.thelocal.fr/20181108/report-the-shocking-truthabout-poverty-in-france-in-2018, e.t. 20.10.2019

Shan, J. \& Khan, M.A. (2014), “Reverse innovation: A new paradigm of innovation Evidence from Chinese markets" BioTechnology An Indian Journal V10(15) ss: 8401-8409

Suri, M. (2019). “India wants to make medical tourism a $\$ 9$ billion industry by 2020”, February 15 ,

Vanham, P.(2017). "Innovation flows from emerging to the developed World", World Economic Forum, May 25, Financial Times, e.t. 29/07/2019, https://www.ft.com/content/c265cb90-4165-11e7-9d56-25f963e998b2

Vernon, R. (1966). "International Investment and International Trade in the Product Cycle", The Quarterly Journal of Economics, v80(2), May, , ss. 190-207

WIPO Magazine, (2013).“Chotukool: Keeping things cool with frugal innovation”, December, https://www.wipo.int/wipo_magazine/en/2013/06/article_0003.html

Wikipedia (2019b). Muhammed Yunus https://en.wikipedia.org/wiki/Muhammad_Yunus

Wikipedia, (2019a). “Poverty in the United States "https://en.wikipedia.org/ wiki/Poverty_in_the_United_States\#cite_note-1

Wikipedia, (2019c). Grameen Bank https://en.wikipedia.org/wiki/Grameen_Bank 25/09/2019

Wikipedia, (2019d). Diffusion of innovations, https://en.wikipedia.org/wiki/Diffusion_of_innovations, e.t. 25/11/2019

World Remit, (2019). https://www.worldremit.com/en/about-us

Zeschky, M., Widenmayer, B., \& Gassmann, O. (2014). “Organising for reverse innovation in Western MNCs: the role of frugal product innovation capabilities", International Journal of Technology Management, 64(2-4), 255-275.

Zmuda, N. (2011). “Marketers Are Increasingly Creating Products in the Developing World and Importing Those Ideas Into More Mature Markets", June 13, AdAge, https://adage.com/article/global-news/p-g-levi-s-ge-innovate-thinking-reverse/228146 